\title{
Cattle Use of Riparian Meadows in the Blue Moun- tains of Northeastern Oregon
}

\author{
R.L. GILLEN, W.C. KRUEGER, AND R.F. MILLER
}

\begin{abstract}
The intensity and pattern of cattle use of small riparian meadows were studied by periodically sampling vegetative standing crop and by continuously monitoring meadows with time-lapse photography. Temperature and relative humidity were also measured in riparian and upland plant communities. Herbage standing crop at the end of the grazing season was similar under continuous grazing and the early and late grazing periods of a two pasture deferredrotation grazing system. Early grazing tended to decrease the total cattle occupation and the frequency of cattle occupation of riparian meadows when compared to continuous grazing. Late grazing tended to increase the frequency of cattle occupation but did not change the total cattle occupation of riparian meadows when compared to continuous grazing. Cattle were present on a given meadow site on about $60 \%$ of all days but for only $3-10 \%$ of the total daylight period. Cattle occupation of riparian meadows was greater during the afternoon hours. The seasonal pattern of cattle occupation was influenced by the location where cattle entered a pasture but not by seasonal temperatures. Temperature and the temperature-humidity index did not differ between riparian and upland plant communities between 12:00 noon and 6:00 p.m.
\end{abstract}

Riparian meadows are narrow, highly productive plant communities occurring along stream courses. These meadows are usually dominated by grasses and grasslike plants but shrubs are often a major vegetative component. Cattle preference for riparian meadows is a major influence on overall grazing distribution on moun-

Authors are assistant professor, Department of Agronomy, Oklahoma State University, Stillwater, and professor and associate professor, Department of Rangeland Resources, Oregon State University, Corvallis, respectively. Miller is located at the Eastern Oregon Agricultural Research Center at Burns, Ore.

This article is submitted as Tech. Paper No. 7064. Oregon Agricultural Experiment Station, Corvallis. This research was supported by funds from the Oregon Range Evaluation Project, USDA-Forest Service. Pacific Northwest Forest and Range Experiment Station.

Manuscript accepted August 20, 1984. tain rangelands.

When forage utilization on meadows reached $75 \%$ on Utah foothill range, forage use on upland slopes averaged only $20 \%$ (Cook and Jeffries 1963). Phillips (1965) reported almost identical results from southern Idaho. Johnson (1965) and McEwen and Dietz (1965) found the intensity of utilization 3-5 times higher on riparian meadows versus forested communities although meadow use did not exceed $50 \%$ in either study. In northeastern Oregon, Roath and Krueger (1982) estimated that $80 \%$ of the forage consumed on a mountain allotment came from the riparian meadows which made up $1.9 \%$ of the total area. Long and Irwin (1982) observed $25 \%$ of the cattle on the $6 \%$ of their study area covered by meadows. Finally, Bryant (1982) made $66 \%$ of his cattle observations on riparian meadows or communities directly adjacent to meadows from late July to early September. The meadows and adjacent communities comprised $5.1 \%$ of the study pastures. However, in late September, only $12 \%$ of the observations were made in the same communities. This shift in habitat use was attributed to complete utilization of forage in the riparian zone; thundershowers, which stimulated new forage growth on the uplands; and a microclimatic shift to more favorable conditions in the uplands (Bryant 1982).

Over the last 2 decades, an increasing amount of attention has been given to the idea that excessive cattle use has reduced the usefulness of the riparian zone for wildlife species, especially fish (Ames 1977, Platts 1979, Thomas et al. 1979). Bowers et al. (1979) summarized 5 studies that indicated an average $200 \%$ increase in trout biomass when improper grazing was controlled and streams were managed for optimum trout habitat. Platts (1981) stated streams impacted by cattle overuse are wider, shallower, warmer, have less overhead cover, and have more fine sediment than unimpacted streams. He further stated livestock impacts are usually 
small cumulative changes that occur over several years (Platts 1982).

Fencing and complete exclusion of grazing from riparian ecosystems is often recommended as a means of controlling livestock impact on riparian meadows (Armour 1979, Behnke and Raleigh 1979, Bowers et al. 1979). While fencing and livestock exclusion would certainly alleviate some aspects of the problem, it does not seem practically feasible on a broad scale and also implies that any level of livestock use would be detrimental. Fencing riparian zones to allow strict control of intensity and season of use seems to be a more reasonable approach. Light to moderate late season grazing has been most often advocated (Bowers et al. 1979, Platts 1981) and has shown good results in practice (Claire and Storch 1977, Kauffman 1982). However, the use of fencing will probably be limited economically to the larger and more important riparian areas (Platts 1979). Small riparian meadows along primary drainages may only range from 5 to $30 \mathrm{~m}$ in width but may total several miles in length in a single mountain range pasture. While these meadows are the riparian areas most susceptible to alteration by cattle grazing (May and Davis 1982), they are also the most difficult areas to fence. If cattle grazing patterns on these long, narrow riparian systems need to be changed, some combination of alternative grazing management practices must be employed.

While all of the usual livestock distribution practices have been suggested as at least partial solutions, the implementation of grazing systems has been given the most attention. Continuous seasonlong or year-long grazing is generally considered to be a detrimental and unacceptable management scheme for riparian meadows (Reid and Pickford 1946; Pond 1961; Platts 1981, 1982), so some type of specialized grazing plan appears necessary. Platts (1981) rated most standard grazing plans as to their ability to maintain quality instream habitat; no system was rated better than fair. He stated none of the present grazing strategies would be satisfactory in this aspect. However, as more data have become available, Platts (1982) has indicated the situation may be better than first thought.

The objectives of this study were to: (a) determine the intensity and pattern of cattle use of small riparian meadows under continuous and deferred rotation grazing management and (b) compare the temperature and relative humidity regimes of riparian and upland plant communities.

\section{Study Area}

The study was conducted on the Upper Middle Fork Grazing Allotment of the Malheur National Forest in north-central Oregon. Elevations range from $1,160 \mathrm{~m}$ along the Middle Fork of the John Day River, which flows northwest through the allotment, to over $2,300 \mathrm{~m}$ on the watershed boundaries. Topography is mountainous with slope gradients ranging from 0 to $100 \%$.

Average annual precipitation ranges from $500 \mathrm{~mm}$ in the valley bottom to $1,010 \mathrm{~mm}$ at the highest elevations. Most of the precipitation falls as snow from November through April. Rain showers occur in May and June. Little precipitation falls in July, August, and early September. During the summer grazing season, daytime maximum temperatures reach $20-30^{\circ} \mathrm{C}$ but frost may occur in any month.

Plant communities on the study area have been described by Hall (1973). About $85 \%$ of the allotment supported forest vegetation. The major forest types included ponderosa pine-Douglas-fir (Pinus ponderosa-Pseudostuga menziesii), mixed conifer, and grand fir (Abies grandis). Riparian meadows were narrow (about $30 \mathrm{~m}$ wide) communities located along streams and covered about $1 \%$ of the study area. Most of these meadows were classified as dry meadows which had surface soils that were wet in spring but had dried by fall and were not sub-irrigated for the entire growing season. Dry meadows were dominated by Kentucky bluegrass (Poa pratensis) with western yarrow (Achillea millefolium), northwest cinquefoil (Potentilla gracilis), and dandelion (Taraxacum officinale) as prominent forbs.
Data were collected in 2 of the 6 pastures of the Upper Middle Fork Grazing Allotment. The Butte Pasture (4,675 ha) was grazed continuously with 85 cow-calf pairs from early June to midOctober except in 1980, when grazing began in early July. The Deerhorn Pasture $(5,735$ ha) was included in a two pasture deferred-rotation grazing system. The system called for all cattle to graze in 1 pasture from early June to early August, at which time the cattle would be moved to the second pasture until mid-October. The direction of livestock movement was reversed in alternate years. The pastures were stocked with 200 cow-calf pairs. The Deerhorn Pasture was grazed in the early period in 1980 and the late period in 1981 .

\section{Herbage Standing Crop}

Materials and Methods

Total standing crop of vegetation on dry riparian meadows was measured at 8 sites on the study area in 1980 and 1981. Four sampling sites were located in each pasture. Total herbage standing crop was sampled at 2-week intervals while cattle were grazing in each pasture. Total herbage on 15 rectangular $0.1-\mathrm{m}^{2}$ quadrats $(30$ $\mathrm{cm} \times 33.3 \mathrm{~cm}$ ) was clipped to ground level on each site on each sampling date. New quadrats were randomly located on each sampling date. Samples of herbage (100-150 gm fresh weight) were dried in a forced-air oven to a constant weight to convert fresh herbage weights to oven-dry weights. Total herbage production without grazing was sampled by clipping 15 quadrats that were protected from grazing by wire cages. Total production sampling was done at the peak of standing crop.

\section{Cattle Occupation}

Cattle use of dry riparian meadows was monitored with timelapse photography in 1980 and 1981 on 2 meadows in each of the study pastures. Battery-powered Super $8 \mathrm{~mm}$ movie cameras were placed on elevated platforms in trees or snags 5-7 m above the ground. The cameras exposed 1 frame of film at 5-minute intervals. Light sensors stopped filming when light levels fell below the minimum required for proper film exposure. Cameras operated continuously while cattle were grazing the study pastures.

Film was analyzed 1 frame at a time using an 8-mm film editor. When cattle appeared in view, the number of animals, their activity, and the time of day was recorded. Time of day was estimated by first counting all frames in a day and calculating the mid-point for that day (solar noon). One-hour intervals were then calculated backwards and forwards from solar noon assuming an average of 12 frame exposures per hour. Only adult cows were counted in the analysis; $95 \%$ or more of the cows on the allotment were nursing calves. The initial unit of measurement was the animal unit frame, defined as 1 cow being present in 1 frame of film. Animal unit frames were then totaled over the season and converted to animal unit days (AUD) by dividing the total animal unit frames by the average number of camera frames exposed per day. Finally, occupation was expressed as AUD per hectare by dividing AUD by the size of the camera view area. View area size was calculated from the length and width of the view area as measured with a steel tape. View areas ranged from 0.12 to 0.26 ha and averaged 0.18 ha.

Peak ungrazed herbage standing crop, herbage standing crop at the end of the grazing season, total cattle occupation, and frequency of cattle occupation (percentage of total camera frames and percentage of total days during which at least 1 cow was present) were compared between grazing systems within years using $t$-tests. Regression analysis was used to characterize the relationship between residual meadow herbage, averaged over pasture, and days of grazing. Correlation was used to associate profiles of daily and season cattle occupation with daily and seasonal climatic conditions.

\section{Microclimate}

The temperature and relative humidity in 3 contrasting plant communities were measured in 1980 and 1981 in 2 drainages located $3.2 \mathrm{~km}$ apart in 1 of the study pastures. Three monitoring stations were established at random in each drainage, one on a 
small riparian meadow, one on a ponderosa pine-Douglas-fir forest site, and one in a small clearcut (1-2 ha) on a ponderosa pine-Douglas-fir-site. Hygrothermographs were placed in wooden louvered shelters 1-1.2 m above the ground surface at each site. Temperature and relative humidity were recorded continuously from mid-June until late September, irrespective of cattle presence in the pasture.

Three variables, temperature, relative humidity, and the temperature-humidity index (THI) averaged between the hours of 12 noon and 6 p.m. were compared among vegetation types. THI integrates temperature and humidity into a single parameter (Thom, 1958) and was calculated as:

$$
\begin{aligned}
& \text { THI }=0.99 \mathrm{~T}_{\mathrm{a}}+0.36 \mathrm{~T}_{\mathrm{d}}+41.5, \text { where } \\
& \mathrm{THI}=\text { temperature-humidity index } \\
& \mathrm{T}_{\mathrm{a}}=\text { air temperature, }{ }^{\circ} \mathrm{C} \\
& \mathrm{T}_{\mathrm{d}} \quad=\text { dew point temperature, }{ }^{\circ} \mathrm{C} .
\end{aligned}
$$

Means were compared among vegetative types within years using a repeated measures analysis of variance with drainages as blocks.

\section{Results}

\section{Herbage Standing Crop}

Peak herbage standing crop on the dry meadows was similar in the 2 pastures in both years and averaged $2,440 \mathrm{~kg} / \mathrm{ha}$ (Table 1).

Table 1. Peak ungrazed herbage standing crop and residual herbage standing crop at the close of grazing ( $\mathrm{kg} / \mathrm{ha}$ ) on riparian meadows.

\begin{tabular}{lccccc}
\hline & & & & \multicolumn{2}{c}{$\begin{array}{c}\text { Residual standing crop } \\
\mathrm{kg} / \mathrm{ha}\end{array}$} \\
\cline { 2 - 3 } \cline { 5 - 6 } Grazing system & 1980 & 1981 & & 1980 & 1981 \\
\hline Continuous & $2490^{1}$ & 2250 & & 570 & 330 \\
& $\pm 330^{2}$ & \pm 260 & & \pm 130 & \pm 45 \\
Deferred- & 2360 & 2650 & & 560 & 350 \\
rotation $^{3}$ & \pm 310 & \pm 330 & & \pm 55 & \pm 25 \\
\hline
\end{tabular}

'All pairs of means within columns are statistically equivalent, $P>10$. 'Standard error

${ }^{3}$ Early grazing in 1980 , late grazing in 1981.

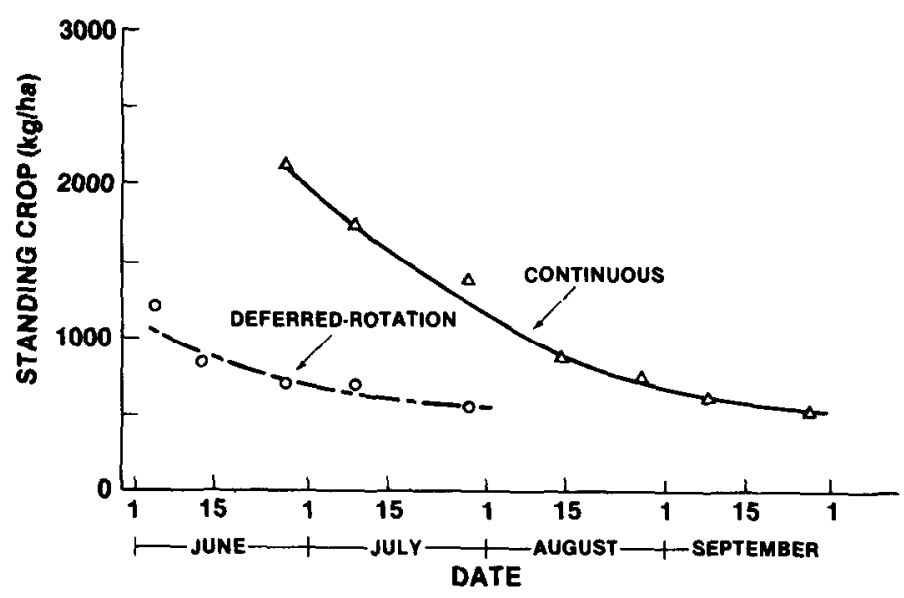

Fig. 1. Standing crop of total herbage on dry riparian meadows, 1980. Each point represents the mean of 4 sampling sites. Curves were calculated from regression equations in Table 2.

The standing crop of herbage on grazed plots decreased continuously throughout the grazing season in both years (Fig. 1 and 2). The rate of decline in standing crop was greatest early in the grazing season and decreased as the amount of available herbage decreased. Negative exponential regression models fit the data well with all regression models accounting for a significant $(P<.05)$ portion of

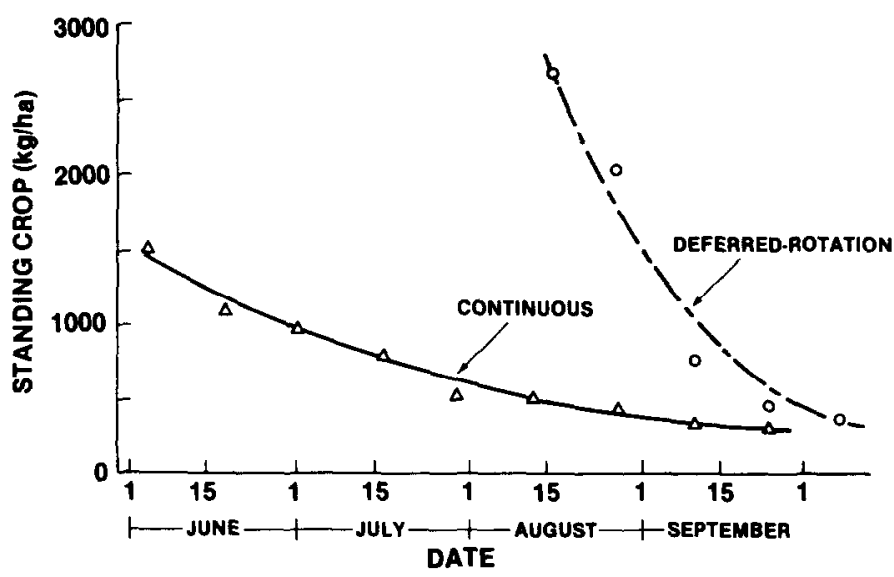

Fig. 2. Standing crop of total herbage on dry riparian meadows, 1981 . Each point represents the mean of 4 sampling sites. Curves were calculated from regression equations in Table 2.

the variation in observations (Table 2). Residual herbage standing crop at the end of the grazing season was similar in both pastures in both years, averaging $565 \mathrm{~kg} / \mathrm{ha}$ in 1980 and $340 \mathrm{~kg} / \mathrm{ha}$ in 1981 (Table 1). Dividing end-of-season standing crop by peak standing crop gave utilization estimates of $77 \%$ in 1980 and $86 \%$ in 1981 , averaged over both pastures.

Table 2. Regression equations relating standing crop on riparian meadows and days of grazing in the pasture.

\begin{tabular}{llll}
\hline Grazing system & Year & Equation 1 & $R^{2}$ \\
\hline Continuous & 1980 & $Y=2026 \mathrm{e}^{-0.02 \mathrm{X}}$ & $.98^{* * 2}$ \\
& 1981 & $\mathrm{Y}=1376 \mathrm{e}^{-0.01 \mathrm{X}}$ & $.97^{* *}$ \\
Deferred-rotation & 1980 & $\mathrm{Y}=1044 \mathrm{e}^{-0.01 \mathrm{X}}$ & $.84^{*}$ \\
& 1981 & $\mathrm{Y}=2674 \mathrm{e}^{-0.04 \mathrm{X}}$ & $.96^{* *}$
\end{tabular}

$\mathrm{I} Y=$ standing crop, $\mathrm{kg} / \mathrm{ha} ; \mathrm{X}=$ days of grazing in pasture

$2 *$ significant at $\boldsymbol{P}<.05 ; *$ significant at $P<01$.

\section{Cattle Occupation}

Total cattle occupation of the dry riparian meadows averaged 78 AUM/ha under continuous grazing but only 33 AUD/ha during the early grazing period of the deferred-rotation system in $1980(P$ $=.11$, Table 3). Total cattle occupation averaged $72 \mathrm{AUD} / \mathrm{ha}$ in 1981 and did not differ between continuous grazing and late season grazing in the deferred-rotation system.

Early season grazing tended to decrease the percentage of camera frames with at least 1 cow present $(P=.17)$ while late season grazing increased the percentage of frames occupied $(P=.13)$ when both were compared to continuous grazing (Table 3). The percentage of days when at least 1 cow was present on the meadows was similar across grazing systems and averaged $60 \%$ (Table 3 ).

It seemed likely that the frequency of occupation might be dependent on view area (plot size) because frequency is not an absolute measure. A similar relation is well known from vegetation sampling (Mueller-Dombois and Ellenberg 1974). However, correlation coefficients between view area and frequency were 0.04 on a total frame basis and 0.0002 on a daily basis $(n=8)$ indicating no association between frequency of cattle occupation and camera view area.

Daily cattle occupation on individual meadows varied greatly through the grazing season. Cattle were present in large numbers or for several hours for 1 or a few days and then were absent for a similar time period. Occupation patterns for individual meadows were influenced by the cattle turn-in point. In 1 example, $25 \%$ of the total cattle occupation on a meadow occurred on the first day 
Table 3. Total occupation (AUD/ha), camera frames occupied (\%), and days occupied (\%) by cattle on riparian meadows.

\begin{tabular}{|c|c|c|c|c|c|c|}
\hline \multirow[b]{2}{*}{ Grazing system } & \multicolumn{2}{|c|}{$\begin{array}{c}\text { Total Occupation } \\
\text { AUD } / \mathrm{hal}^{\prime}\end{array}$} & \multicolumn{2}{|c|}{ Frames occupied, $\%$} & \multicolumn{2}{|c|}{ Days occupied $\%$} \\
\hline & 1980 & 1981 & 1980 & 1981 & 1980 & 1981 \\
\hline Continuous & $\begin{array}{r}78 \\
\pm 12^{2}\end{array}$ & $\begin{array}{r}66 \\
\pm 18\end{array}$ & $\begin{array}{r}5.5 \\
\pm 0.7\end{array}$ & $\begin{array}{r}5.8 \\
\pm 0.6\end{array}$ & $\begin{array}{l}61 \\
\pm 9\end{array}$ & $\begin{array}{r}57 \\
\pm 2\end{array}$ \\
\hline Deferred-rotation ${ }^{3}$ & $\begin{array}{r}33 \\
\pm 9 \\
\end{array}$ & $\begin{array}{r}78 \\
\pm 33 \\
\end{array}$ & $\begin{array}{r}3.9 \\
\pm 0.1 \\
\end{array}$ & $\begin{array}{r}8.6 \\
+0.9 \\
\end{array}$ & $\begin{array}{r}61 \\
\pm 0.5 \\
\end{array}$ & $\begin{array}{r}61 \\
\pm 11 \\
\end{array}$ \\
\hline Probability & .11 & .50 & .17 & .13 & .50 & .50 \\
\hline
\end{tabular}

'AUD = Animal Unit Days

2 Standard error

'Early grazing in 1980 , late grazing in 1981

of grazing because the cattle were turned into the pasture $0.8 \mathrm{~km}$ downstream from the observation site. In another example, one monitored meadow was on the east side of the deferred-rotation pasture and the second was on the west side. The cattle turn-in point shifted from the east side to the west side depending on whether the pasture was grazed early or late. Meadows near the turn-in point were grazed immediately while the meadows on the opposite end of the pasture received no utilization for 7 to 14 days. Cattle occupation patterns on individual meadows did not respond to seasonal or to forage utilization. Cattle occupation did not increase during July and August, the hottest months of the year, and did not decrease as herbage standing crop decreased.

Within days, proportion of total cattle occupation was low during the morning hours. Cattle use increascd sharply around 11:00 a.m., rose to a peak in late afternoon, and dropped sharply again near dusk. Both grazing systems exhibited this pattern, with the peak of occupation varying between 2:00 and 6:00 p.m. Totaled over grazing system and year, $78 \%$ of all cattle occupation of riparian meadows occurred after 12:00 noon.

On the riparian meadows, cattle spent $74 \%$ of the time grazing, $13 \%$ standing, and $9 \%$ lying. Averaged over all plant communities (meadows and uplands), cattle spent $63 \%$ of the time grazing, $22 \%$ standing, and $10 \%$ lying (Gillen 1982). The differences in grazing and standing times between meadows alone and all plant communities were significant $(p<05)$. Increased emphasis on grazing while cattle are on riparian meadows would tend to increase the disproportion between levels of herbage utilization on meadow and upland plant communities.

\section{Microclimate}

There were few statistically significant differences in afternoon averages of microclimatic parameters between riparian meadows, forests, and clearcuts (Table 4). Cattle are considered to be under heat stress at THI values greater than 70 (Johnson et al. 1962, Cargill and Stewart 1966, Ehrenreich and Bjugstad 1966). Averaged over years, the percentage of days with THI values greater than 70 was $25 \%$ for the riparian meadows, $23 \%$ for forests, and $25 \%$ for clearcuts.

Table 4. Means of microclimatic variables bet ween 12 noon and $6 \mathrm{p} . \mathrm{m}$. for three vegetation types.

\begin{tabular}{lllll}
\hline \hline $\begin{array}{l}\text { Microclimatic } \\
\text { variables }\end{array}$ & Year & $\begin{array}{l}\text { Riparian } \\
\text { meadow }\end{array}$ & Forest & Clearcut \\
\hline Temperature $\left({ }^{\circ} \mathrm{C}\right)$ & 1980 & 20.2 & 20.1 & 19.9 \\
& 1981 & 24.6 & 25.8 & 25.0 \\
Relative & 1980 & $39.1^{\text {ad }}$ & $35.7^{\mathrm{a}}$ & $37.6^{\mathrm{ab}}$ \\
humidity (\%) & 1981 & $23.8^{\mathrm{a}}$ & $22.6^{\mathrm{b}}$ & $22.3^{\mathrm{b}}$ \\
Temperature- & 1980 & 63.1 & 62.7 & 62.6 \\
humidity index & 1981 & 66.5 & 67.0 & 66.6 \\
\hline
\end{tabular}

Means followed by different letters with columns are significantly different, $P<10$.

\section{Discussion}

Cattle exerted sufficient grazing pressure to remove as much herbage as possible from the dry riparian meadows under both grazing systems. Herbage standing crop approached similar basal levels below which little additional forage removal occurred. Final stubble heights were seldom greater than $5 \mathrm{~cm}$ and were sometimes less than $2.5 \mathrm{~cm}$. Basal levels were reached rapidly in the deferredrotation pasture in 1980 (early grazing) when low starting herbage levels were combined with higher animal numbers under deferredrotation grazing.

While final utilization levels were similar between the 2 grazing systems, the pattern of forage utilization was different. Herbage in the early and continuous grazing periods was grazed early in the growth cycle with no allowance for accumulation of regrowth (no regrowth occurred after July). In the late grazing period, the herbage had completed most of its growth cycle before being grazed. Based on available information, it appears the early and continuous grazing treatments would be most detrimental to the meadow plants (Pond 1961, McLean et al. 1963). However, more research is necessary to determine the effects of various schedules of defoliation on the herbaceous plants of riparian meadows. In addition, shrubs and trees are important components of riparian vegetation and their response to grazing schedule should receive attention.

When the magnitude and frequency of cattle occupation are considered together, there was a trend for early grazing to decrease cattle occupation on the dry meadows compared to continuous grazing. Forage nutrient contents on upland sites would be at their highest point during the early grazing period (Skovlin 1967) and temporary water supplies would still be available in the uplands. These 2 factors would reduce the relative attractiveness of the riparian meadows during the early grazing period although they would still be preferred over the uplands (Gillen et al. 1984).

Cattle occupicd any single riparian site fairly often (high daily frequency) but did not stay on that site for long periods of time (low total frequency). Though present for a small proportion of the total time, cattle still had enough time to remove considerable amounts of forage. Martin (1979) also observed a low total frequency of cattle occupation on a riparian zone in central Arizona.

In terms of temperature and relative humidity, the microclimate in the riparian zone was as stressful as the microclimate of the surrounding uplands. The concept of an overall superiority of the riparian microclimate over the upland microclimate in relation to cattle heat stress was not supported in this study. However, 2 other parameters, wind and radiation, must be measured along with temperature and humidity to fully compare the microclimates of the contrasting plant communities.

Major reasons often given for the attractiveness of riparian meadows to cattle, as already discussed, are large amounts of nutritious palatable herbage, moderate slope gradient, reliable water supply and more favorable microclimate. At the onset of grazing, there was definitely more herbage available on the dry meadows $(2,440 \mathrm{~kg} / \mathrm{ha})$ than on the adjacent uplands $(200-500$ 
$\mathrm{kg} / \mathrm{ha}$ ). The amount of riparian herbage soon decreased to low levels while adjacent upland forage was utilized an average of only 8-12\% (Gillen et al. 1984). Cattle continued to use the riparian meadows even as the herbage levels decreased to the physical limits of grazing. These cattle were almost certainly reducing the rate of forage intake per unit of time spent grazing. Johnstone-Wallace and Kennedy (1944) reported cattle often overconsumed forage on Kentucky bluegrass pastures when it was highly available and then depressed intake severely when the amount of herbage dropped to lower levels. Cattle that continued to use riparian meadows with low levels of available herbage probably depressed animal production and may have preconditioned themselves for later physiological disorders (Roath 1980).

The moderate slope gradients of riparian meadows were an attractant to cattle on this mountain allotment for use as resting areas and travel routes. However, there were also many active and closed roads, railroad grades, topographic benches, and ridgetops that could have served the same purpose and covered much larger areas than the riparian meadows.

The riparian meadows with their attendant streams offered a more reliable water source than upland water developments. Many of these developments on the allotment were small, shallow ponds which became dry by late summer. However, ponds and troughs built near the better flowing springs did hold water for the entire summer. Streams still had an advantage over these developments in the quality of their free-flowing water as compared to water held in an impoundment.

The riparian meadows did not always possess more favorable habitat characteristics than could be found in upland situations, especially after appreciable herbage removal had occurred on the meadows. More likely, it was the unique placement of all of these characteristics in a single community that made the meadows so attractive. At various times through the season, each of these factors acted alone and in combination with the others to maintain the uniform high preference of these sites by cattle.

Finally, some flexibility in managing riparian meadow use is available by changing the cattle turn-in point for a pasture. The start of grazing on a particular meadow may be changed by as much as 2 weeks in these relatively large range pastures depending on where cattle enter the pasture. While the final intensity of use would not differ, the timing of use of a particular meadow could be modified. This suggests the possibility of an internal pasture rotation that could be alternated among years. Also, the length of the actual grazing period for an area of critical concern or special interest could be shortened by turning cattle onto the pasture at a point far removed from the area of interest.

\section{Literature Cited}

Ames, C.R. 1977. Wildlife conflicts in riparian management: Grazing. p. 49-51. In: Johnson and D.A. Jones, ed. Importance, Preservation, and Management of Riparian Habitat: A Symposium. USDA Forest Serv., Gen. Tech. Rep. RM-43.

Armour, C. 1979. Livestock management approaches and the fisheries resource. p. 39. In: O.B. Cope, ed. Proc. of the Forum-Grazing and Riparian/Stream Ecosystems. Trout Unlimited, Inc.

Behnke, R.J., and R.F. Raleigh. 1979. Grazing and the riparian zone: Impact and management perspectives. p. 263-267. In: R.R. Johnson and J.F. McCormick, eds. Strategies for Protection and Management of Floodplain Wetlands and Other Riparian Ecosystems. USDA Forest Serv. Gen. Tech. Rep. WO-12.

Bowers, W., B. Hosford, A. Oakley, and C. Bond. 1979. Wildlife habitats in managed rangelands-the Great Basin of southeastern Oregon. Native Trout. USDA Forest Serv. Gen. Tech. Rep. PNW-84.

Bryant, L.D. 1982. Response of livestock to riparian zone exclusion. J. Range Manage. 35:780-785.

Cargill, B.F., and R.E. Stewart. 1966. Effect of humidity on total heat and total vapor dissipation of Holstein cows. Trans. Amer. Soc. Agr. Engr. 9:702-706. ire, E.W., and R.L. Storch. 1983. Streamside management and livestock grazing: An objective look at the situation. In: J.W. Menke, ed. Proc. of the Workshop on Livestock and Wildlife-Fisheries Relationships in the Great Basin. Univ. of Calif.-Berkeley, Div. of Agr. Sci. Spec. Publ. 3301.

Cook, C.W., and N. Jeffries. 1963. Better distribution of cattle on mountain ranges. Utah Farm and Home Sci. 24:31.

Ehrenreich, J.H., and A.J. Bjugstad. 1966. Cattle grazing time is related to temperature and humidity. J. Range Manage. 19:141-142.

Gillen, R.L. 1982. Grazing behavior and distribution of cattle on mountain rangelands. Ph.D. Diss., Oregon State Univ., Corvallis.

Gillen, R.L., W.C. Krueger, and R.F. Miller. 1984. Cattle distribution on mountain rangeland in northeastern Oregon. J. Range Manage. J. Range Manage. 37:549-553.

Hall, F.C. 1973. Plant communities of the Blue Mountains in eastern Oregon and southeastern Washington. USDA Forest Serv., Pac. NW Region, R6 Area Guide 3-1.

Johnson, H.D., A.C. Ragsdale, J.L. Berry, and M.D. Shanklin. 1962. Effect of various temperature-humidity combinations on milk production of Holstein cattle. Mo. Agr. Exp. Sta. Res. Bull. 791.

Johnson, W.M. 1965. Rotation, rest-rotation, and season-long grazing on mountain range in Wyoming. USDA Forest Serv. Res. Pap. RM-14.

Johnstone-Wallace, D.B., and K. Kennedy. 1944. Grazing management practices and their relationship to the behavior and grazing habits of cattle. J. Agr. Res. 34:190-197.

Kaufiman, J.B. 1982. Synecological effects of cattle grazing riparian ecosystems. MS Thesis, Oregon State Univ., Corvallis.

Long, A.J., and L.L. Irwin. 1982. Elk-cattle interactions in the Bighorn Mountains, Wyoming. p. 553-563. In: J.M. Peek and P.D. Dalke, ed. Wild life-Livestock Relations Symposium: Proc. 10. Univ. Idaho, Forest, Wildl, and Range Exp. Sta., Moscow.

Martin, S.C. 1979. Evaluating the impacts of cattle grazing on riparian habitats. p. 35-38. In: O.B. Cope, ed. Proc. Forum-Grazing and Riparian/Stream Ecosystems. Trout Unlimited.

May, B.E., and B. Davis. 1982. Practices for livestock grazing and aquatic habitat protection on western rangelands. p. 271-278. In: J.M. Peek and P.D. Dalke, eds., Wildlife-Livestock Relationships Symposium: Proc. 10. Univ. Idaho, Forest, Wildl, and Range Exp. Sta., Moscow.

McEwen, L.C., and D.R. Dietz. 1965. Shade effects on chemical composition of herbage in the Black Hills. J. Range Manage. 18:184-190.

McLean, A., H.H. Nicholson, and A.L. Van Ryswyk. 1963. Growth, productivity, and chemical composition of a sub-alpine meadow in interior British Columbia. J. Range Manage. 16:235-240.

Mueller-Dombois, D., and H. Ellenberg. 1974. Aims and methods of vegetation ecology. Wiley and Sons.

Phillips, T.A. 1965. The influence of slope gradient, distance from water, and other factors on livestock distribution on national forest cattle allotments of the Intermountain region. USDA Forest Serv. Intermount. Forest and Range Exp. Sta., Range Improvement Notes. 10:9-19.

Platts, W.S. 1979. Livestock grazing and riparian/stream ecosystesm-an overview. p. 39-45. In: O.B. Cope, ed. Proc. Forum-Grazing and Riparian/Stream Ecosystems. Trout Unlimited, Inc.

Platts, W.S. 1981. Effects of livestock grazing. In: W.R. Meehan, Tech. ed. Influence of Forest and Rangeland Management on Anadramous Fish Habitat in Western North America. USDA Forest Serv. Gen. Tech. Rep. PNW-124.

Platts, W.S. 1982. Sheep and cattle grazing strategies on riparian-stream environments. p. 251-270. In: J.M. Peek and P.D. Dalke, eds. WildlifeLivestock Relations Symposium: Proc. 10. Univ. Idaho, Forest, Wildl., and Range Exp. Sta., Moscow.

Pond, F.W. 1961. Effect of three intensities of clipping on the density and production of meadow vegetation. J. Range Manage. 14:34-38.

Reid, E.H., and G.D. Pickford. 1946. Judging mountain meadow range condition in eastern Oregon and eastern Washington. USDA Circ. 748.

Roath, L.R. 1980. Cattle grazing habits and movements related to riparian habitats and forest ranges with inference to acute dietary bovine pulmonary emphysema. Ph.D. Diss., Oregon State Univ., Corvallis.

Roath, L.R., and W.C. Krueger. 1982. Cattle grazing and behavior on a forested range. J. Range Manage. 35:332-338.

Skovlin, J.M. 1967. Fluctuations in forage quality on summer range in the Blue Mountains. USDA Forest Serv. Res. Paper PNW-44.

Thom, E.C. 1958. Cooling-degree days. Air-cond., Heat., and Vent. 55:65-72.

Thomas, J.W., C. Maser, and J.E. Rodiek. 1979. Riparian zones in managed rangelands-their importance to wild life. p. 21-30. In:O.B. Cope, ed. Proc. of the Forum-Grazing and Riparian/Stream Ecosystems. Trout Unlimited, Inc. 